\title{
Evaluation of Chilli Genotypes for Growth and Fruit Yield Attributing Traits under Chhattisgarh Plain Conditions
}

\author{
Versha Kumari*, J. Singh, D. Sharma and Sunidhi Mishra
}

Department of Vegetable Science, Indira Gandhi Krishi Vishwavidyalaya, Raipur, (C.G) - 492012, India

*Corresponding author

\author{
A B S T R A C T
}

\begin{tabular}{|l|}
\hline Ke y w o r d s \\
$\begin{array}{l}\text { Chilli, ANOVA, Mean } \\
\text { performance, Fruit } \\
\text { yield. }\end{array}$ \\
\hline Article Info \\
\hline $\begin{array}{l}\text { Accepted: } \\
\text { 26 September } 2017 \\
\text { Available Online: } \\
\text { 10 November } 2017\end{array}$ \\
\hline
\end{tabular}

In order to evaluate the performance of sixteen genotypes of Chilli for fruit yield and its component traits, the present experiment was laid under randomized complete block design with three replications at Indira Gandhi Krishi Vishwavidayalaya (IGKV), Raipur during rabi season of 2016-17. Analysis of variance revealed that the genotypes differed significantly for all the characters namely, days to first flowering, days to $50 \%$ flowering, plant height $(\mathrm{cm})$, number of primary branches, stem girth $(\mathrm{cm})$, days to first picking, fruit length $(\mathrm{cm})$, fruit girth $(\mathrm{cm})$, stalk length $(\mathrm{cm})$, number of seeds per fruit, number of fruits per plant, fresh weight of fruits (gm), dry weight of fruits (gm), dry matter \% of fruits, fruit yield per plant $(\mathrm{gm})$, fruit yield per plot $(\mathrm{kg})$, fruit yield per ha (q) indicating the existence of the enough amount of variability in the material studied. Mean performance of all the genotype for different characters was studied and the genotype namely, 2014/CHIVAR-9 was found to give highest total fruit yield plot $^{-1}$. Fruit yield per plot ranged from $8 \mathrm{~kg}$ to $19.52 \mathrm{~kg}$ with an overall mean of $14.03 \mathrm{~kg}$. The highest total fruit yield was recorded in genotype 2014/CHIVAR-9, which was statistically at par with the performance of Kashi Anmol-2 (18.50 Kg), 2014/CHIVAR-7(17.83 kg), 2014/CHIVAR-10 (16.99 kg) and 2016/CHIVAR-6 (15.9 kg). Genotype 2016/CHIVAR-5 (8 kg) was yielded minimum fruit yield per plot.

\section{Introduction}

Chilli is the most economic and popular additive to improve food acceptability. It is grown for use as a vegetable (green chilli) and spice (dry chilli) under tropical, subtropical and temperate climates. The presence of capsaicin in chilli is responsible for its pungency and it has medicinal value as well. It also contains vitamin A (292.04 IU), vitamin C $(143.7 \mu \mathrm{g})$, vitamin $\mathrm{K}(14 \mu \mathrm{g})$, vitamin $\mathrm{E}(0.69 \mathrm{mg})$, and other minerals. A wealth of information and scientific evidences are rapidly accumulating on the beneficial effects of wide variety of food components on human health. The most important vitamin in fruits and vegetables is vitamin C. Chilli is quite high in other nutritive value containing moisture $(87.7 \mathrm{~g})$, protein $(2.9 \mathrm{~g})$, carbohydrate $(3.0 \mathrm{~g})$, fiber $(6.8 \mathrm{~g})$, it has covered a vast agricultural area throughout the country and contributes an important share in Indian table food. Although the crop is available throughout the year, the demand of chilli is further increasing with the expanding population. A wide range of 
variability reportedly exists in this crop. Therefore, the present study was aimed at comparison of different chilli genotypes to identify and select the most appropriate one with enhanced potential for growth and yield in Chhattisgarh plain conditions.

\section{Materials and Methods}

The present experiment was conducted at Indira Gandhi Krishi Viswavidayalaya (IGKV), Raipur during rabi season of 201617 in order to evaluate the performance of sixteen genotypes of chilli for various yield and its component traits under field condition with three replications of each genotype. Each plot measuring $4.2 \times 3.5 \mathrm{~m}^{2}$ had six rows spaced at $60 \mathrm{~cm}$ apart with intra-row spacing of $50 \mathrm{~cm}$. The chilli seeds were planted during second week of September, 2016. The recommended dose of fertilizer i.e. nitrogen $150 \mathrm{Kg}$, phosphorus $75 \mathrm{Kg}$ and potassium 60 $\mathrm{Kg}$ per hectare was applied. Half nitrogen was applied at the time of planting and remaining was applied in two splits i.e., at 30 and 60 DAP. Crop was visited regularly throughout the growing season and intercultural operations such as weeding, irrigation and plant protection measures were performed as and when necessary. The study on analysis of variance and mean performance of genotypes was carried out for different growth and yield parameters.

\section{Results and Discussion}

\section{Analysis of variance}

Analysis of variance revealed that mean sum of squares due to genotypes was found to be highly significant (at 1\% level of significance) for Days to first flowering, Days to $50 \%$ flowering, Plant height $(\mathrm{cm})$, Number of primary branches, Stem girth (cm), Days to first picking, Fruit length $(\mathrm{cm})$, Fruit girth $(\mathrm{cm})$, Stalk length $(\mathrm{cm})$, Number of seeds per fruit, Number of fruits per plant, Fresh weight of fruits (gm), Dry weight of fruits (gm), Dry matter $\%$ of fruits, Fruit yield per plant (gm), Fruit yield per plot $(\mathrm{Kg})$, Fruit yield per ha (q). This suggested the presence of substantial amount of genetic variation among the genotypes that could be exploited in selection for desirable traits. All the above findings are in close agreement with the findings of Sahu et al., (2016) for total fruit yield and number of shoots; Janaki et al., (2016) and Patel et al., (2014) who reported variability for flowering, fruit size, number of fruit per plant, fruit weight and yield/plant. The result of analysis of variance for all the characters under study is presented in Table 1.

Mean performance of genotype for different characters

Mean performance of genotypes for various growth and yield attributing traits is presented in Table 2 and the results are explained below:

\section{Plant height (cm)}

Plant height ranged from 33.37 to $66.50 \mathrm{~cm}$ with an overall mean of $55.01 \mathrm{~cm}$. Genotype 2014/CHIVAR-4 was recorded for maximum plant height and lowest plant height was recorded in Kashi Anmol - 2.

\section{Stem girth (cm)}

Stem girth ranged from $3.41 \mathrm{~cm}$ to $4.88 \mathrm{~cm}$ with an overall mean of $4.11 \mathrm{~cm}$. Genotype 2012/CHIVAR-8 was recorded with maximum stem girth and lowest stem girth was recorded in 2016/CHIVAR-3.

\section{Number of primary branches per plant}

Number of primary branches ranged from 9.73 to 2.93 with an overall mean of 6.49 . Genotype 2016/CHIVAR-4 was recorded 
with maximum number of primary branches and lowest Number of primary branches was recorded in 2016/CHIVAR-3.

\section{Days to first flowering}

The first flowering date ranged from 35 days to 58.67 days with an overall mean of 47.29 days.

Earliest flowering was recorded in 2016/CHIVAR-4 and delayed flowering was recorded in 2014/CHIVAR-2.

\section{Days to $50 \%$ flowering}

Days to $50 \%$ flowering ranged from 43.67 days to 69.30 days with an overall mean of 59.65 days. Earliest $50 \%$ flowering was recorded in 2016/CHIVAR-4) and delayed
$50 \%$ flowering was recorded in 2016/CHIVAR-2.

\section{Days to first picking}

Days taken to first green fruit picking ranged from 91 days to 103.11 days with an overall mean of 99.48 days. Earliest harvest was recorded in the genotype 2016/CHIVAR-5 whereas, maximum days to first fruit picking was recorded in the genotype 2014/CHIVAR2.

\section{Fruit length (cm)}

Length of fruit ranged from $8.09 \mathrm{~cm}$ to 13.84 $\mathrm{cm}$ with an overall mean of $8.99 \mathrm{~cm}$. Genotype 2014/CHIVAR-9 was recorded for maximum fruit length lowest fruit length was recorded in genotype 2016/CHIVAR-5

Table.1 Analysis of variance for fruit yields and its component

\begin{tabular}{|c|c|c|c|c|}
\hline \multirow{4}{*}{ S. No. } & \multirow{4}{*}{ Characters } & \multicolumn{3}{|c|}{ Mean Sum of Square } \\
\hline & & Replication & Treatments & Error \\
\hline & & \multicolumn{3}{|c|}{ Degree of freedom } \\
\hline & & 2 & 15 & 30 \\
\hline 1 & Days to first flowering & 39.400 & $142.440 * *$ & 21.550 \\
\hline 2 & Days to $50 \%$ flowering & 14.330 & $215.890 * *$ & 13.870 \\
\hline 3 & Plant height $(\mathrm{cm})$ & 21.590 & $261.710 * *$ & 10.350 \\
\hline 4 & Number of primary branches & 0.410 & $17.630 * *$ & 0.570 \\
\hline 5 & Stem girth $(\mathrm{cm})$ & 0.090 & $0.640 * *$ & 0.050 \\
\hline 6 & Days to first picking & 0.271 & $52.176 * *$ & 3.760 \\
\hline 7 & Fruit length $(\mathrm{cm})$ & 0.100 & $7.960 * *$ & 0.253 \\
\hline 8 & Fruit girth $(\mathrm{cm})$ & 0.036 & $4.333 * *$ & 0.012 \\
\hline 9 & Stalk length (cm) & 0.054 & $0.599 * *$ & 0.084 \\
\hline 10 & Number of seeds per fruit & 59.391 & $478.556 * *$ & 22.766 \\
\hline 11 & Number of fruits per plant & 47.206 & $1285.059 * *$ & 360.741 \\
\hline 12 & Fresh weight of fruits (gm) & 22.602 & $295.842 * *$ & 9.451 \\
\hline 13 & Dry weight of fruits (gm) & 0.083 & $18.565 * *$ & 0.424 \\
\hline 14 & Number of pickings & 0.583 & 0.617 & 0.317 \\
\hline 15 & Dry matter $\%$ of fruits & 9.440 & $117.407 * *$ & 3.397 \\
\hline 16 & Fruit yield per plant (gm) & 337.133 & $12928.090 * *$ & 870.557 \\
\hline 17 & Fruit yield per plot (Kg) & 2.838 & $33.389 * *$ & 2.757 \\
\hline 18 & Fruit yield per ha (q) & 129.553 & $1543.586 * *$ & 127.934 \\
\hline
\end{tabular}

* Significant at 5\% level of significance, ** Significant at $1 \%$ level of significance 
Int.J.Curr.Microbiol.App.Sci (2017) 6(11): 3478-3483

Table.2 Mean performance for fruit yield and its components in chilli

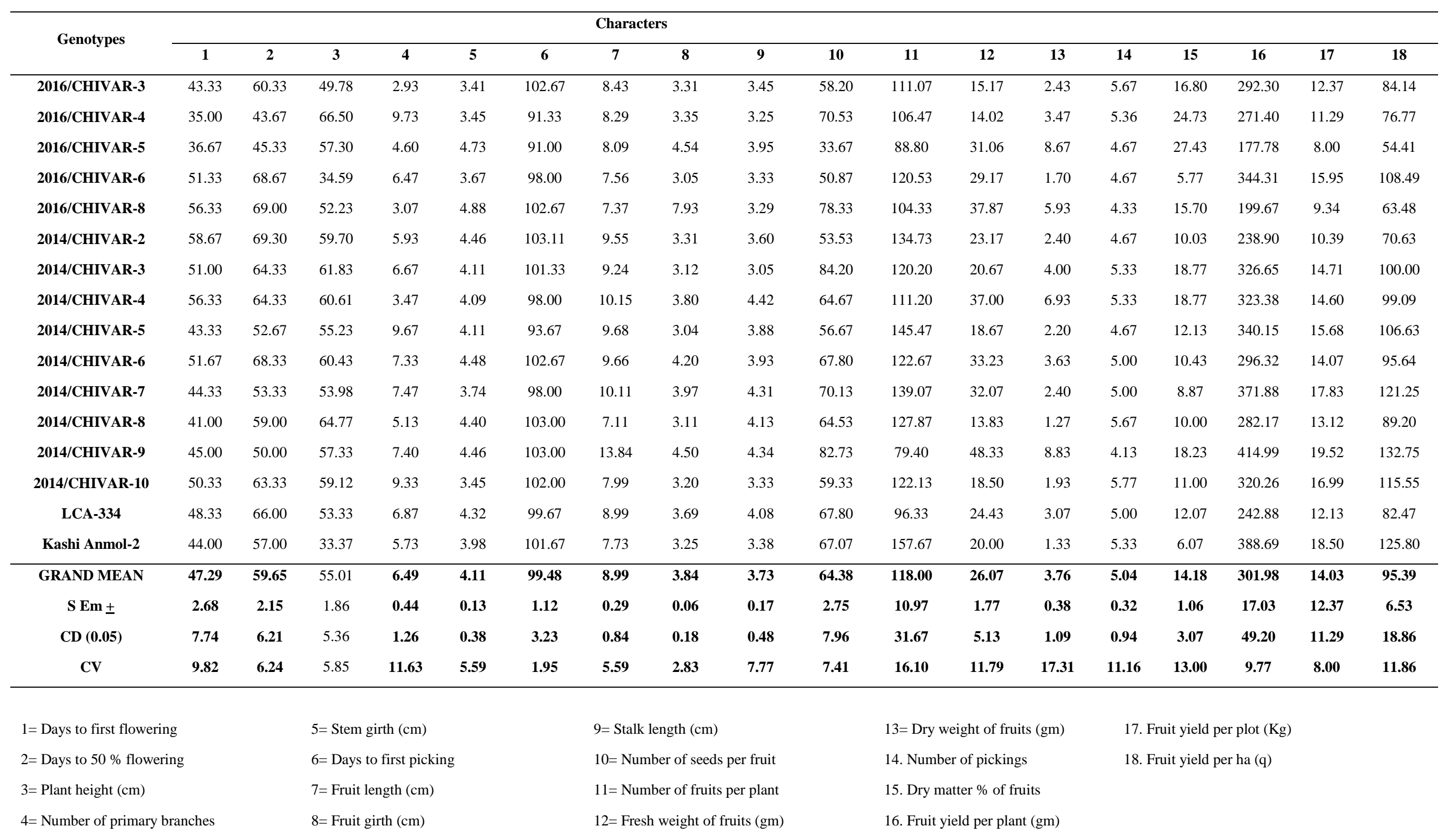




\section{Fruit girth (cm)}

Fruit girth ranged from $3.04 \mathrm{~cm}$ to $7.93 \mathrm{~cm}$. with an overall mean of $3.84 \mathrm{~cm}$. Genotype 2016/CHIVAR-8 was recorded maximum fruit girth and lowest fruit girth was recorded in genotype 2016/CHIVAR-5.

\section{Fresh weight of fruit (g)}

Fresh weight of fruits ranged from $13.83 \mathrm{gm}$ to $48.33 \mathrm{gm}$. Genotype 2014/CHIVAR-9 was recorded maximum fresh weight of fruits with an overall mean of $26.07 \mathrm{~g}$.

\section{Number of fruits per plant}

Among the genotypes number of fruits per plant ranged from 79 to 157.67 with an overall mean of 118 fruits per plant. Maximum number of fruits per plant was recorded in the genotype Kashi Anmol-2 and genotype 2014/CHIVAR-9 was yielded minimum number of fruits per plant.

\section{Fruit yield per plant (g)}

Fruit yield per plant ranged from 177.78 gm to $414.99 \mathrm{gm}$ with an overall mean of 301.98 gm. Maximum fruit yield per plant was recorded in the genotype 2014/CHIVAR-9 and genotype 2016/CHIVAR-8 was yielded minimum fruit yield per plant.

\section{Fruit yield per plot (kg)}

Fruit yield per plot ranged from $8 \mathrm{~kg}$ to 19.52 $\mathrm{kg}$ with an overall mean of $14.03 \mathrm{~kg}$. Maximum fruit yield per plot was recorded in the genotype 2014/CHIVAR-9 and genotype 2016/CHIVAR-5 was yielded minimum fruit yield per plot.

\section{Fruit yield (q/ha)}

Fruit yield quintal per hectare ranged from 54 to $132.75 \mathrm{q}$ with an overall mean of $95.39 \mathrm{q}$.
Maximum fruit yield quintal per hectare was recorded in the genotype 2014/CHIVAR-9 and genotype 2016/CHIVAR-5 (54 q) was yielded minimum fruit yield quintal per hectare.

Analysis of variance revealed significant mean sum of squares for all the characters studied indicating the presence of variability among the genotypes. Thus, it could be concluded that there exists a lot of genetic variation among the genotypes and improvement could be brought through simple selection. On the basis of mean performance of genotypes for different characters, the varieties namely, 2014/ CHIVAR-9, 2014/CHIVAR-7, 2014/ CHIVAR-10 and 2014/CHIVAR-5 showed best performance in terms of total fruit yield $\operatorname{plot}^{-1}$. Thus, the above mentioned varieties can be recommended to be grown in order to achieve higher production in the region.

\section{References}

Hasan, M. J., Kulsum, M. U., Ullah, M. Z., Hossain, M. M and Mahmud, M. E. 2014. diversity of some chilli (Capsicum annuиm L.) genotypes. Int. J. Agril. Res. Innov. Tech. 4 (1): 32-35.

Janaki, M., Naram Naidu, L., Venkata Ramana, C. and Paratpara, M.R. 2016. Genetic divergence among chilli (Capsicum annuum L.) genotypes based on quantitative and qualitative traits. I.J.S.N. 7 (1): 181-189.

Jogi, M.Y., Madalageri, M.B., Pujari, R.J. and Mallimar, M.S. 2015. Genetic variability studies in chilli (Capsicum annuит L.) for yield and quality attributes. Indian journal of ecology. 42(2): 536-539.

Kumar, D., Bahadur, V., Rangare, S.B. and Singh, D. 2012. Genetic variability, heritability and correlation studies in chilli (Capsicum annuum L.). Hortflora Research Spectrum. 1(3): 248-252. 
Patel, K.L., Sarnaik, D.A., Sharma, D. and Mehta, N. 2014b. Genetic variability studies in chilli (Capsicum annuum L.). Plant development Sci. 6(2): 321- 384.

Sahu, L., Trivedi, J. and Sharma, D. 2016. Genetic variability, heritability and divergence analysis in chilli (Capsicum annuит L.). Plant Archives. 16(1): 445-
448.

Yatung, T., Dubey, R.K., Singh, V. and Upadhyay, G. 2014. Genetic diversity of chilli (Capsicum annuum L.) genotypes of India based on morpho chemical traits. Australian J. Crop. Sci. 8(1): 97-102.

\section{How to cite this article:}

Versha Kumari, J. Singh, D. Sharma and Sunidhi Mishra. 2017. Evaluation of Chilli Genotypes for Growth and Fruit Yield Attributing Traits under Chhattisgarh Plain Conditions. Int.J.Curr.Microbiol.App.Sci. 6(11): 3478-3483. doi: https://doi.org/10.20546/ijcmas.2017.611.409 